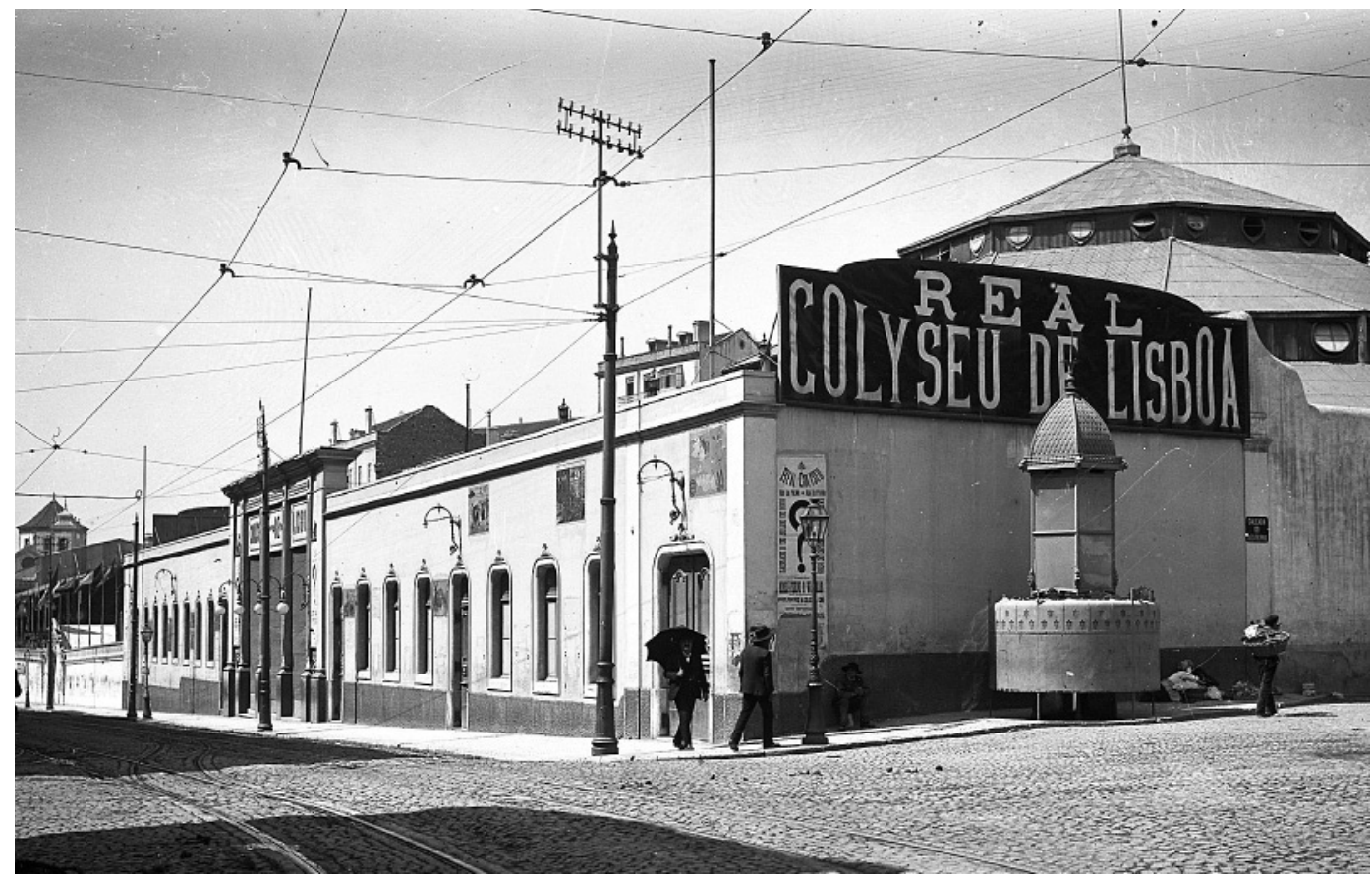

Real Coliseu de Lisbo [Cortesia do Arquivo

\title{
República, cinema e espectáculo As fitas e o discurso do poder
}

\author{
Jorge Seabra
}

É já há muito conhecido que as primeiras projecções cinematográficas começaram em Portugal em 1896, um ano depois da mostra pública promovida pelos Lumière em Paris. Porém, a nossa informação já é mais escassa ao nivel da forma como este tipo de espectáculo se organizou, bem como sobre o dispositivo legal que o poder estruturou para o regulamentar. Saber como se processou a recepção que o poder político concedeu a este tipo de divertimento, particularmente durante o período republicano, nomeadamente sobre as normas existentes ao nivel da organização do espectáculo e sobre o controlo dos conteúdos exibidos, é o objectivo deste texto, procurando enquadrar, através da legislação produzida para o sector, a forma como a Primeira República foi regulamentando o então chamado "espectáculo das fitas" e,

simultaneamente, perceber qual o pensamento subjacente ao discurso do poder.

\section{Ao serviço da nação}

A emergência educativa e propagandística do cinema Embora seja já sobejamente conhecida a importância que os republicanos atribuiram à escola como "instituição socializadora de conhecimentos e valores" (Catroga 1991: 379), colocando-a ao serviço da libertação do homem em relação ao obscurantismo e à servidão que séculos de educação religiosa haviam incutido no povo português, não é de surpreender não encontrarmos ainda qualquer medida legislativa que indicie a utilização educativa do cinema no sistema de ensino, apesar das preocupações de inovação pedagógica patenteadas, nomeadamente pela divulgação do método de João de Deus baseado na Cartilha maternal (Marques 1980: 83-88). Afinal, o cinema - nas primeiras décadas do século - estava ainda em processo de implantação como arte e como indústria, daí que o seu potencial educativo não tivesse ainda sido ponderado pelas instituições oficiais.

Apesar dessa situação, no declinar do período republicano já vamos encontrar dois diplomas onde subjaz o seu carácter educativo e doutrinador. Em 1925, a coligação governamental entre democráticos de esquerda, seareiros e "alvaristas", liderados por José Domingues dos Santos, impôs a todos os cinematógrafos de Lisboa e Porto a obrigação de realizarem "duas vezes por mês uma sessão cinematográfica educativa, de hora e meia, na qual terão admissão gratuita as crianças das escolas primárias oficiais, acompanhadas de um professor de cada escola" (Lei 1748, 1925: art. 20). Por sua vez, em 1926, o governo democrático liderado por António Maria da Silva, acerca das exibições normais de cinema, recomenda o cuidado que deve pautar a escolha de filmes a exibir nas sessões diurnas, "as mais frequentadas pela população infantil", devendo "sempre presidir um critério pedagógico geral, de modo a obterse deste género de espectáculos a máxima eficácia educativa" (Decreto 11459, 1926: art.o 4º).

Parece-nos que estes dois diplomas são já indiciadores de alguma dimensão educativa atribuida ao cinema,
Jorge Humberto Seabra é Doutorado em História

Contemporânea pela Faculdade de Letras da Universidade de

Coimbra, com uma tese intitulada África Nossa O império colonial na ficção cinematográfica portuguesa (1945 1974). Com o apoio da Fundação para a Ciência e Tecnologia, desenvolve

actualmente um dicionário temático sobre legislação na área do cinema, produzida entre 1895 e 1974. 
Cartaz do

Animatógrafo

do Rossio Recreios

\section{ARGUMENTO}

Da fita de grande saccesso, em $\&$ partes

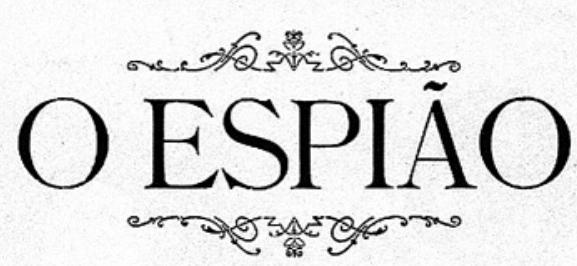

BPISODIOS DA ACTUAL GUBRRA BOROPBIA

\section{QUINTA-FEIRA, 10}

NO

\section{Xinimatographo do Rocio}

(Aroo do Bandeira)
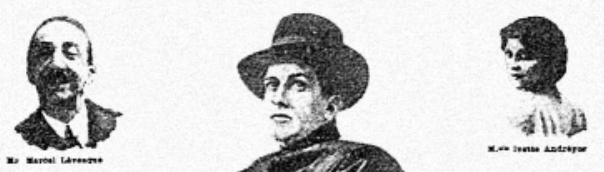

GOLYSEU DOS RECREIOS

Sabbado, 10 (a) 9 basa 6 astit)

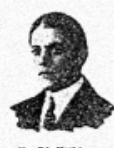

STREII da Ultima Moyidate Cinematorrafit

A NOVA MISSÃO
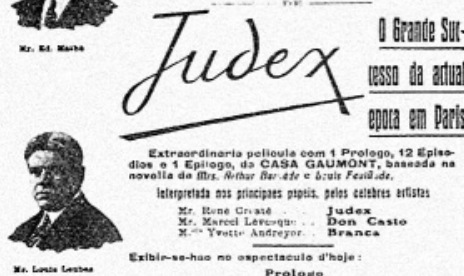

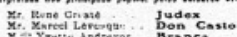

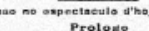

A RAZZIA DOS SEGREDOS

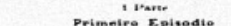

o mYSTERIO D'UMAa nOITE de VERÃo

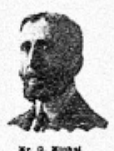
s.

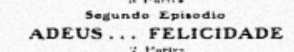

Tereeiro $\mathrm{E}_{\text {pisodio }}$

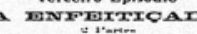

conckKTo MUSACA

PRECOS DOS BILHETES S: direccionada essencialmente para as camadas que frequentam a escola primária. Porém, no conjunto do período, para além de surgirem tardiamente, e pela sua escassez, representam uma abordagem tímida ao aproveitamento doutrinador da sétima arte. De qualquer forma, o mote estava lançado e, no que se refere a este potencial do cinema, não notaremos qualquer interrupção com o advento do Estado Novo.

Porém, a atenção do poder político não se confinará à vertente educativa. Poderemos igualmente referir que será durante o periodo republicano que emergem as primeiras iniciativas para colocar o meio cinematográfico ao serviço da nação através da propaganda política. Essa atenção a esta vertente surge em consonância com aquilo que se passava em alguns estados ocidentais, dado que será durante a guerra de 1914-1918 que assistiremos ao aparecimento da propaganda organizada, com o objectivo de criar consensos em torno das opções políticas dos estados beligerantes, através da divulgação de informações destinadas a incutirem na população uma imagem negativa do inimigo e positiva das cores nacionais. Essas opções conduziram ao aparecimento dos primeiros organismos de propaganda, como o Departamento de Propaganda na Inglaterra, o Comité de Informação Pública nos Estados Unidos, ambos surgidos em 1917, ou através da "imprensa dos documentários cinematográficos, dos bilhetes postais, de cartazes, da canção patriótica" e de outras publicações para os casos da França e da Alemanha (Paulo 1994: 14 Taylor 1982)

Nessa linha, durante o republicanismo surgirá o primeiro organismo de propaganda cinematográfica. Em 1918, durante o consulado de Sidónio Pais, é instituída a Seç̧ão Fotográfica e Cinematográfica do Exército, criada por iniciativa do Ministério da Guerra liderado pelo próprio Sidónio, do qual resultou uma estrutura que envolvia já um conjunto significativo de meios técnicos e humanos Estaremos seguramente perante o primeiro organismo de propaganda surgido em Portugal, cujo aparecimento nos parece condicionado pelo contexto da guerra, à semelhança de outros organismos congéneres criados por outros países igualmente participantes no conflito. Desse modo, esta primeira intenção propagandistica deverá ser entendida numa lógica defensiva do estado e não tanto com os intuitos doutrinários de republicanização do país. De qualquer forma, trata-se da primeira iniciativa do poder que, apesar de ter como primordial objectivo "registar para serem utilizados na projecção fixa e animada todos os assuntos relativos à educação e preparação do exército, na paz e na guerra", deveria captar, ao mesmo tempo, "tudo quanto [pudesse] aproveitar à instrução, à educação física, e à propaganda de Portugal no estrangeiro" (Decreto 4214, 1918: $\operatorname{art.}^{\circ} 2^{\circ}$ ).

Um espectáculo fiscalmente contributivo A última dimensão onde poderemos verificar a colocação do meio cinematográfico ao serviço da nação será através do domínio fiscal. Apesar de não sabermos em rigor de quando datam as primeiras decisões do poder político no sentido de tornar as actividades relacionadas com as artes de representação sujeitos passivos de contribuição fiscal, logo no início do século, em 1901, aparece-nos um decreto a tributar através de imposto de selo a publicação de "cartazes ou anúncios de espectáculos públicos" (Decreto 1901: art.o 12), facto que será confirmado no ano seguinte, com a publicação da tabela geral do imposto de selo, onde, para além dos cartazes, serão também objecto de tributação os bilhetes de entrada nos espectáculos (Decreto 1902).

Os republicanos irão manter estes impostos

implementados pela Monarquia Constitucional, acrescidos de outros, nomeadamente a exigência do imposto de selo desde 1921, na concessão de licenças para espectáculos (Decreto 7772, 1921). Em 1922, substituindo o imposto de selo sobre os bilhetes, surge o imposto sobre o valor das transacções, sendo desde então cobrado " $2 \%$ sobre a receita bruta das entradas nas casas de espectáculos públicos" (Lei 1368, 1922: art. $^{\circ} 4^{\circ}$ ). 


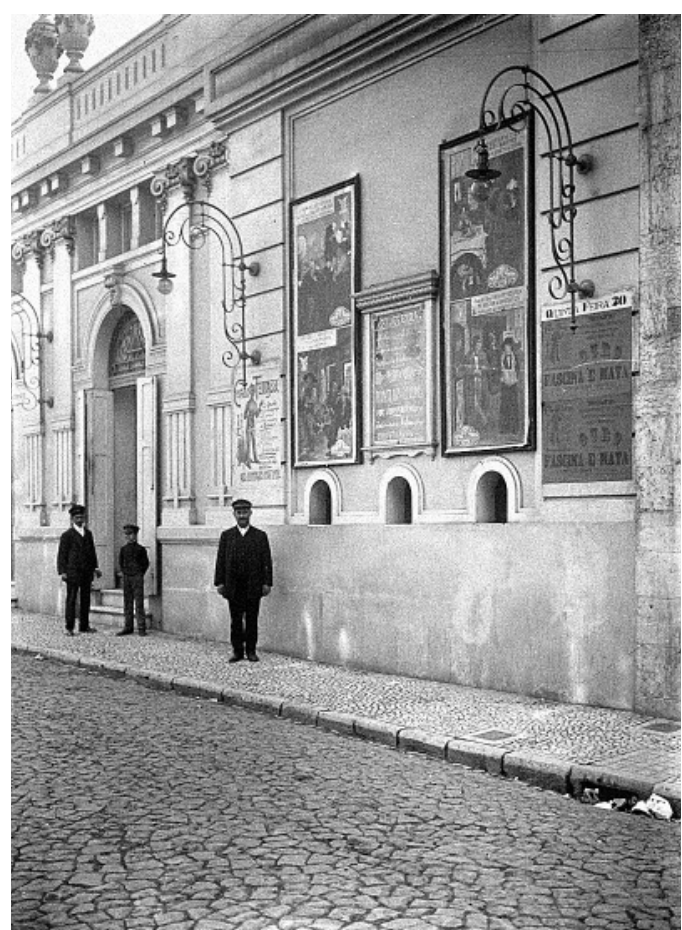

Finalmente, em 1924, numa actualização da tabela do imposto de selo, aparecem as primeiras medidas fiscais de que temos conhecimento com aplicação exclusiva sobre os filmes. Desde então, os "animatógrafos exibindo um ou mais films de indústria portuguesa" eram colectados em 5\% de imposto; os espectáculos cinematográficos em que exclusivamente se exibissem "films estrangeiros" com 10\%; quando as empresas cinematográficas não renovassem, "em cada periodo de 30 dias, os films de indústria portuguesa" que exibissem, o imposto de selo, enquanto não se fizesse a renovação, passaria a ser de 10\%; por fim, desta contribuição ficavam sujeitos à taxa mínima de $\$ 10$ os cinemas que exibissem "exclusivamente films com carácter educativo" (Lei 1633, 1924: art. 2º).

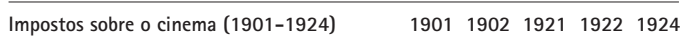
Anos

\begin{tabular}{llllll}
\hline Selo sobre bilhetes de espectáculos & & $x$ & $x$ & & $x$ \\
\hline Selo sobre cartazes de espectáculos & $x$ & $x$ & $x$ & & \\
\hline Selo sobre licenças para espectáculos & & & $x$ & & \\
\hline Imposto sobre o valor das transacções & & & & $\times$ & \\
\hline Selo sobre a exibição de filmes & & & & & \\
\hline
\end{tabular}

Deste modo, apesar de somente nos anos 20 surgirem os primeiros diplomas tributários com incidência directa sobre o cinema, não encontrámos nos diplomas anteriores que consultámos nenhum regime de excepção em relação aos filmes, pelo que somos levados a concluir que, a partir de 1901, os espectáculos de cinema estariam sujeitos à contribuição fiscal, tal como os restantes espectáculos públicos.

\section{A condição social dos profissionais de cinema}

Como vimos, apesar da juventude do cinema, verificámos já algum interesse do poder em colocar este espectáculo ao serviço da nação. Ante essa demonstração, importará indagar também o retorno jurídico e social que o poder
Chiado Terrasse

[Cortesia do Arquivo

Municipal de Lisboa:

Arquivo Fotográfico]. foi proporcionando aos profissionais do cinema por essa prestação, olhando para todo o conjunto de profissões inseridas no ramo, avaliando a sua condição social, quer na configuração jurídica que a lei lhes reconhece, quer no tipo de assistência médico-social que o estado Ihes proporcionou. Dado que o cinema movimenta um leque alargado de profissões, na sua maioria menos visiveis do que a de realizadores e actores, é aqui que o discurso do poder adquire pertinência, regulamentando, tanto nas obrigações como nas regalias, e é por aí que pretendemos responder à questão do reconhecimento social que foi conferido aos profissionais deste sector.

\section{A propriedade cinematográfica}

0 reconhecimento jurídico da propriedade intelectual e artistica existe em Portugal desde 1851 (lei da propriedade literária de Garrett, 8 de Julho). Em 1911, através de um decreto do então governo provisório de 18 de Março, Portugal aderia à Convenção de Berna. Esta convenção foi aprovada numa reunião efectuada na Suiça em 1886, entre a Alemanha, Inglaterra, Bélgica, França, Espanha, Itália, República do Haiti, República da Libéria, Suiça e Tunísia, e da qual emergiu a União Internacional de Propriedade Intelectual. Surgirão entretanto dois actos adicionais ao texto inicial, um de 1896 em Paris, e outro de 1908 em Berlim, já com representação portuguesa, do qual resultou a versão que o governo provisório subscreveu. Este tratado virá a tornar-se a norma internacional para a defesa da propriedade intelectual e artística, bem como dos respectivos direitos de autor até meados do século, tendo sofrido novas modificações em Berna (1914), Roma (1928), Bruxelas (1948) e Paris (1971). Em 1952 surge a Convenção Internacional do Direito de Autor, um novo instrumento jurídico-internacional sobre esta matéria. Será o papel social conferido à instrução que levará os republicanos a dignificarem a "função intelectual", englobando nesta a "produção de ideias e a manifestação de sentimentos", efectuada por "pensadores e sábios (...) literatos e artistas", ou seja, a "elite intelectual que [constituía] a consciência nacional em acção". Essa dignificação, que passava pelo reconhecimento da propriedade intelectual, era tanto mais justa quanto "não se compreendia que se protegesse a indústria, o comércio e a propriedade material e não se fizesse o mesmo aos produtos do pensamento humano". Desse modo, era uma questão de justiça "assegurar a propriedade individual da obra que germinou no espírito do pensador, ou que [nasceu] da fantasia do poeta e do artista". Simultaneamente, dever-se-ia "assegurar a tais produtos da inteligência e da emoção a protecção reciproca nos vários países", em direcção a uma "cultura universal", que contribuía para o estreitamento "das relações internacionais" numa base que garantia a "continuidade da civilização" (Decreto 1911: preâmbulo). 
Imbuída neste espirito de confraternização universal através das ideias e de elevação da cultura dos povos, a jovem república portuguesa subscrevia também pela Convenção de Berna a elevação da obra cinematográfica à categoria de manifestação artística idêntica às restantes. Dizia-se então no texto que eram "protegidas como obras (...) artísticas as produções cinematográficas, quando, pelos dispositivos de mise-en-scène ou pelas combinações de incidentes representados, o autor tiver dado à obra um carácter pessoal e original. [E], sem prejuizo dos direitos de autor de obra original, a reprodução pela cinematografia de uma obra literária, científica ou artística [era também] protegida como uma obra original" (Convenção de Berna art. ${ }^{14}$ ). Uma importante ilação é possivel aferir deste reconhecimento: os países europeus signatários colocavam o cinema, ainda jovem manifestação cultural, no mesmo patamar de artes como a pintura, a escultura ou a literatura.

0 estatuto profissional e a assistência médico-social $\mathrm{Na}$ linha do vazio legislativo anterior, podem também ser referenciados o estatuto profissional e a assistência médico-social. Apesar de datarem do periodo republicano os primeiros diplomas que definem o conceito de artista assim como as primeiras medidas tomadas no sentido de enquadrar estatutariamente o desenvolvimento da profissão, o discurso do poder em nenhum decreto faz qualquer referência aos profissionais do espectáculo cinematográfico. 0 primeiro diploma com o intuito de dignificar a carreira dos artistas dramáticos surge em 1924, exigindo-se desde então uma licença emitida pela Inspecção Geral dos Teatros para o exercício da profissão, "sem a apresentação da qual nenhuma autoridade poderá visar cartazes ou autorizar espectáculos" (Decreto 9764, 1924: art. $\left.{ }^{10}\right)$. Em 1925, o poder republicano virá ainda a definir o que entende por "artistas dramáticos", englobando nesse grupo "todos os individuos, nacionais ou estrangeiros, que se exibam em espectáculos públicos, representando, cantando, executando pantominas, bailados ou peças histriónicas congéneres, quer se apresentem isoladamente, quer em conjunto com outros artistas" (Decreto 10798, 1925: art.o 1). Trata-se de uma matéria onde o vazio persistirá, prolongando-se durante o Estado Novo, sem que exista qualquer razão objectiva para esta omissão, a não ser a persistência da filiação profissional do cinema no universo do teatro.

A mesma situação se aplica à assistência social. 0 poder republicano nunca promulgou qualquer diploma para a área dos profissionais do espectáculo, continuando a persistir os mecanismos de organização particular de assistência médico-social que já vinham da Monarquia Constitucional. Efectivamente, existia uma tradição assistencialista entre os actores teatrais - que encontramos na legislação desde 1846 e se prolonga pela República que originou a permanente criação de Caixas de Socorros
Mútuos, destinadas a apoiar os mutualistas em casos de aposentação e doença, quadro que começa a inverter-se a partir de 1943 com a criação da Caixa de Previdência dos Profissionais do Espectáculo, momento a partir do qual o Estado vai começar a assumir a responsabilidade da criação e gestão de organismos destinados à assistência social, opção que deve ser entendida no conjunto das tendências do tempo, nomeadamente na implementação do estado-providência.

\section{0 espectacular sob vigilância}

\section{O devir espectacular de uma indústria perigosa}

0 carácter inflamável e explosivo das películas dos primeiros tempos do cinema, fabricadas em nitrato de celulose, fará com que, desde cedo, o poder republicano venha a classificar a indústria cinematográfica como perigosa, carácter a que o espectáculo cinematográfico não ficava imune. Logo em 1913, devido àquele perigo, o poder republicano classificou os "depósitos de fitas cinematográficas" como "estabelecimentos perigosos" (Decreto 1913a). Em 1918, pela primeira vez, é elaborado um diploma sobre indústrias insalubres com inconvenientes para a segurança pública, onde surgem determinações relativas aos espectáculos públicos. No entanto, será em 1922 que é publicado o primeiro "regulamento das indústrias insalubres, incómodas, perigosas ou tóxicas", onde as oficinas de celulóide, os depósitos de fitas cinematográficas em cidades e o seu fabrico, são inseridas na tabela que oferece maior grau de perigosidade, precisamente o risco de incêndio (Decreto 8364, 1922: tabela I). Finalmente, em 1925, os governos republicanos virão a reconsiderar a decisão anterior, inserindo estes materiais na segunda tabela, aquela que oferecia menos problemas públicos (Decreto 10443, 1925: art. ${ }^{2}{ }^{\circ}$ ).

No que diz respeito ao espectáculo, para além das normas de segurança comuns aos seus congéneres, nomeadamente ao nivel da ordem pública e da prevenção de incêndios na construção, o evento cinematográfico val ser regulamentado através de um conjunto de normas específicas provenientes do referido carácter inflamável das películas, problema que vai confluir na concepção da cabina de projecção. A primeira questão fora já objecto de regulamentação pelo poder republicano em 1913. Então, nas prescrições de segurança para cinematógrafos era determinado que o aparelho de projecção seria "colocado numa cabina construída ou revestida interiormente com materiais incombustiveis". Naquela, só poderia estar a fita em serviço, conservando-se as outras "encerradas em caixas metálicas e em local isolado do público e ventilado", e os lugares para os espectadores não poderiam "ser estabelecidos a menos de dois metros da cabina" (Decreto 1913b: art.os 1, 2º, 12º). Em 1917, reconhecendo-se os prejuizos que esta última disposição 


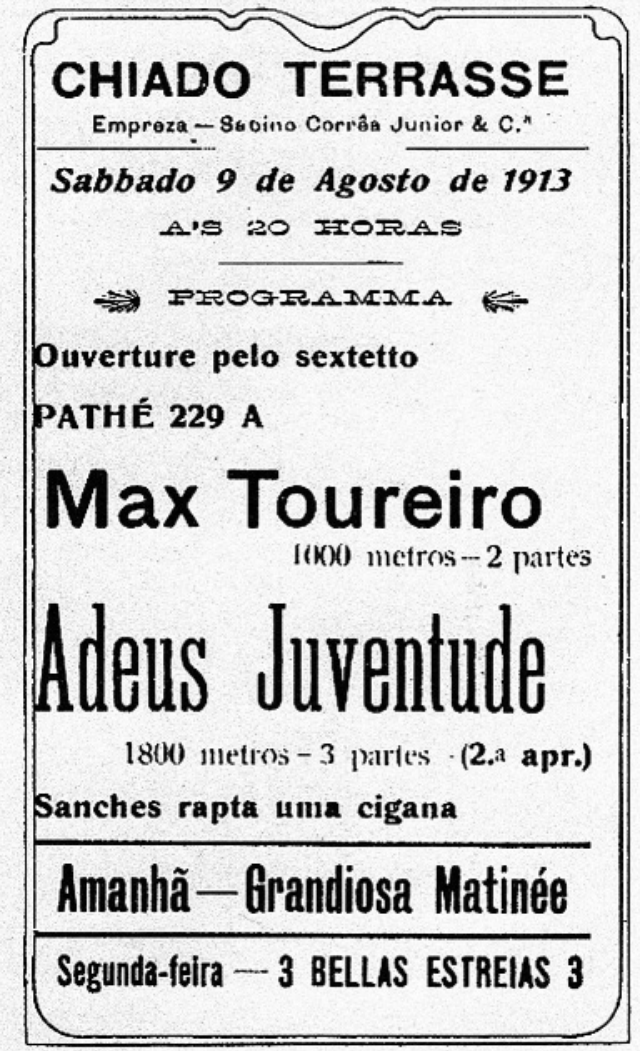

provocava nas empresas exploradoras, mantinha-se o mínimo de dois metros de distância, "salvo nos casos [em] que a fiscalização técnica do governo [considerasse] isentos dessa exigência" (Decreto 3098, 1917: $\operatorname{art.~}^{\circ} 2^{\circ}$ ).

A perigosidade inerente ao espectáculo cinematográfico virá a ser agravada a partir de 1931 com a utilização da energia de alta tensão exigida para o filme sonoro, apesar de aquela ter sido prematuramente proibida no decreto regulamentador de 1927 (Decreto 13564, 1927: art. ${ }^{51} 1^{\circ}$. Apesar de o risco inerente a este evento ter em parte diminuido com a descoberta da película em acetato, dir-se-ia que a evolução do espectáculo cinematográfico exigia que este convivesse sempre com factores de risco, primeiro oriundos do tipo de película, depois devido ao tipo de energia, questões que viriam a obrigar as autoridades políticas a terem uma atenção redobrada no dispositivo de segurança que se prolongaria e aprofundaria para além do período republicano.

\section{0 aparecimento da censura às fitas}

Implantada a República em 1910, o novo poder vai encontrar-se na contingência de aplicar algumas medidas restritivas, entre as quais vamos encontrar a censura, para tentar travar a convulsão revolucionária que se instalou no pais após a eleição de Manuel de Arriaga para a Presidência da República. Efectivamente, esta eleição de 24 de Agosto de 1911, concretizada através do apoio das facções de António José de Almeida e Brito Camacho, a que se opôs a facção de Afonso Costa que apoiava Bernardino Machado, vai marcar o fim da unanimidade republicana e o início de um período de confrontação política, onde se oporão evolucionistas, unionistas e democráticos. Para além da divisão entre republicanos,

\section{COLYSEU DOS RECREIOS \\ Domingo, 8 de Dezembro de 1917 \\ Descle as 2 horas da tarde \\ ULTIMOS Espectaculos \\ Antes da apresentaşion $\mathrm{em}$ L.jisboa th \\ Celebre Companaia de BAILES RUSSOS}
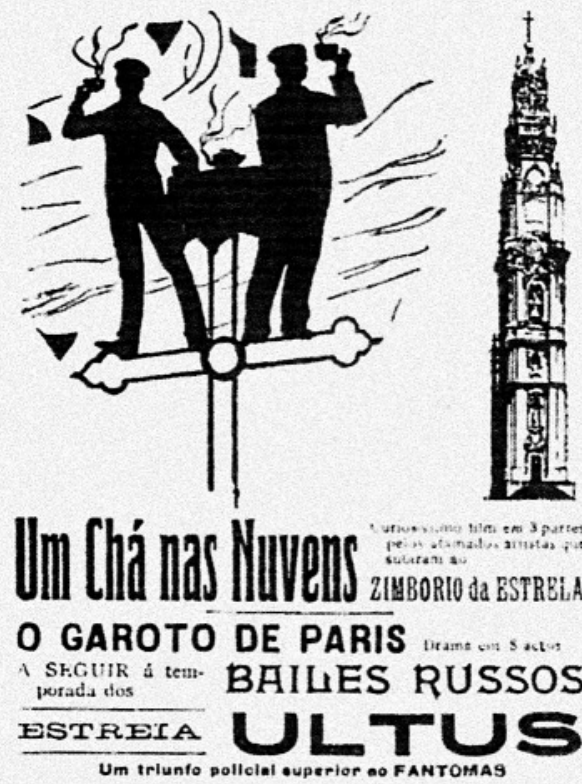

Cartaz do Coliseu dos

verificar-se-á alguma agitação operária, em alguns casos materializada em greves e, entre Outubro de 1911 e Outubro de 1912, dar-se-ão três tentativas contrarevolucionárias lideradas por Paiva Couceiro.

0 resultado desta instabilidade será a tomada de um conjunto de medidas repressivas, logo em fins de Janeiro de 1912, durante o governo de Augusto de Vasconcelos, em virtude de uma greve geral, de que resultará a instauração do estado de sítio, a censura prévia à imprensa e o recolher obrigatório (Ramos 1994a: 465). Em Julho de 1912, no rescaldo da segunda incursão monárquica ocorrida entre 6 e 8, o governo de Duarte Leite decide que "aquele que por qualquer meio de propaganda tendenciosa ou subversiva, verbal ou escrita, pública ou clandestina, aconselhar, instigar ou provocar os cidadãos portugueses ao não cumprimento dos seus deveres militares, ou ao cometimento de actos atentatórios da integridade e independência da pátria, será punido com a pena de prisão correccional de trinta dias a um ano e multa de 50 a 500 escudos" (Decreto, 1912: art.o 10).

A conjuntura decorrente da participação portuguesa na Grande Guerra conduzirá o poder a instituir pela primeira vez a censura às fitas, constituindo o dado mais significativo que o discurso do poder republicano apresenta relativamente à vigilância sobre o cinema. Trata-se de uma medida que se insere na lógica da guerra, idêntica à dos restantes países envolvidos, decorrente das exigências da defesa nacional ao nivel do controlo da retaguarda, nomeadamente da informação sobre a guerra, de forma a poder exercer a influência desejada sobre a opinião pública. 0 decreto, datado de 10 de Setembro de 1917, é o último de um conjunto de diplomas com medidas similares mas para áreas distintas daquele. 
Animatógrafo do Rossio [Cortesia do Arquivo Municipal de Lisboa: Arquivo Fotográfico]

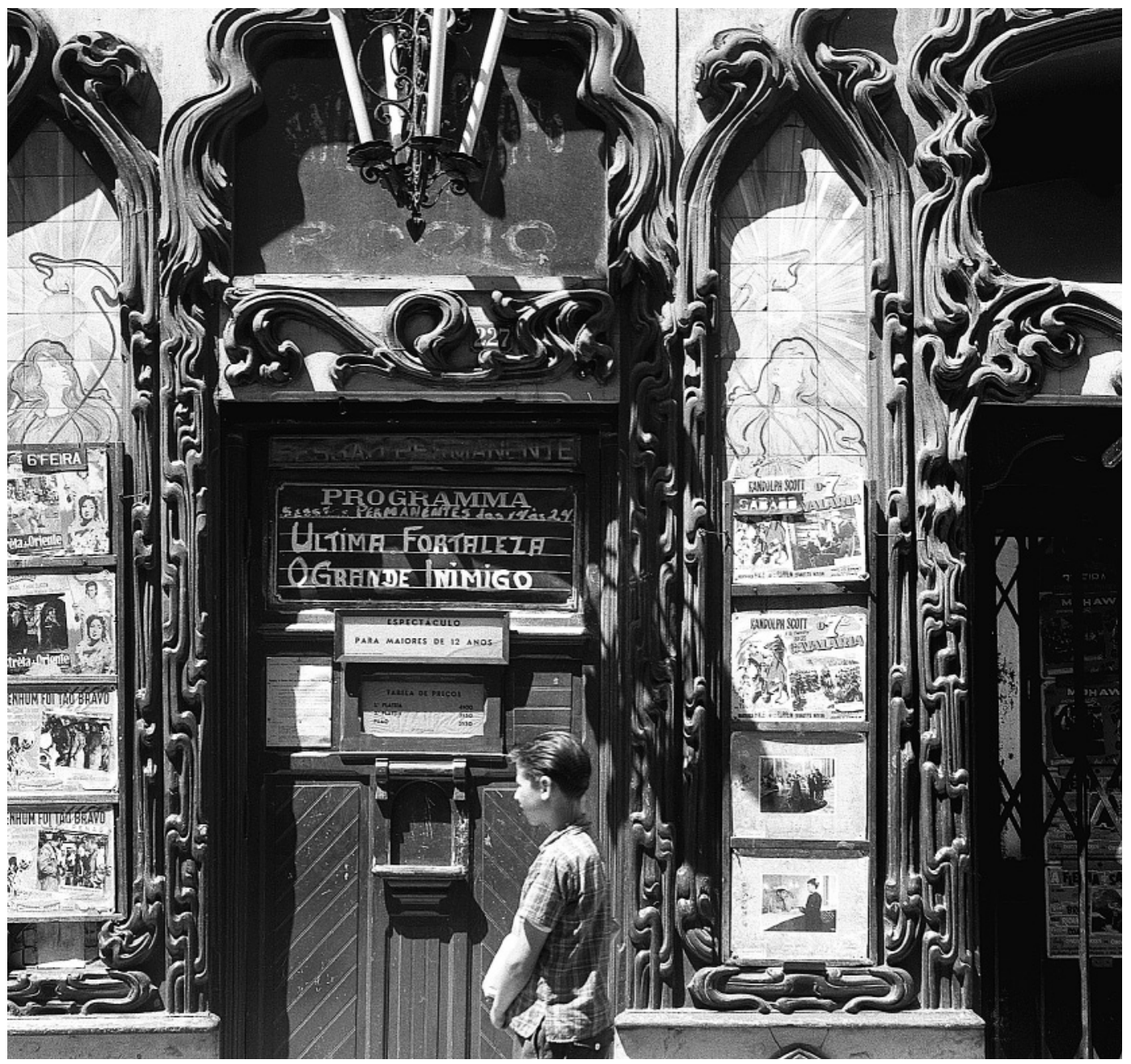

Logo a 12 de Março de 1916, dias depois de a Alemanha ter declarado guerra a Portugal, em nome dos "interesses nacionais" e da "imperiosa necessidade de manter e defender a ordem pública", é "permitido às autoridades policiais ou administrativas apreender ou mandar apreender os periódicos", bem como outros tipos de publicações, "nos quais se divulgue boato ou informação capaz de alarmar o espírito público ou de causar prejuizo ao estado, no que respeita, quer à segurança interna ou externa, quer aos seus interesses em relação a nações estrangeiras, ou ainda aos trabalhos de preparação ou execução de defesa militar" (Decreto 2270, 1916: art. $^{0}$ 10). $^{\circ}$

Complementando aquela decisão, a 28 de Março era instituída a "censura preventiva aos periódicos e outros impressos, (...) aos escritos ou desenhos de qualquer modo publicados" (Lei 495, 1916: art.o 1), passando a existir comissões de censura distritais nomeadas pelo Ministro do Interior, e concelhias indicadas pelos governadores civis (Decreto 2308, 1916: rrt. $^{\circ} 2^{\circ}$ ). A 20 de Abril surgia a censura postal e telegráfica (Decreto 2352, 1916). A 31 de Julho a censura preventiva aos periódicos e outras publicações era alargada às colónias (Decreto 2538, 1916). A 16 de Março de 1917, as mercadorias eram também objecto do mesmo procedimento (Decreto 3036, 1917). Finalmente, a 20 de Setembro do mesmo ano, surgia a censura prévia às fitas, à responsabilidade do Ministério da Guerra, e à qual importadores ou exibidores estavam obrigados.
10 Nenhuma fita cinematográfica, de qualquer natureza ou proveniência, queue contenha assuntos militares, ou que directa ou indirectamente faça alusão aos exercicios beligerantes ou à grande guerra, poderá ser exibida nos territórios da República sem previamente ser sujeita à censura militar:

$2^{\circ}$ Os importadores ou proprietários das referidas fitas devem solicitar o seu exame prévio e o competente documento de livre exibição ao Ministro da Guerra (...)

$3^{\circ}$ As fitas que forem encontradas em contravenção [...] serão apreendidas e os seus proprietários ou empresários autuados por desobediência (Decreto 3354, 1917).

A chegada de Sidónio Pais ao poder em finais de 1917 não vai alterar no essencial as disposições censórias anteriormente em vigor, apesar de terem sido publicados novos decretos sobre o assunto (Decreto 4082, 1918; Decreto 4436, 1918; Decreto 4601, 1918; Decreto 4927, 1918). Terminada a guerra e já depois do interregno sidonista, a censura postal e telegráfica era revogada no governo de Canto e Castro por terem "cessado as causas que determinaram o [seu] emprego" (Decreto 5455, 1919).

No entanto, o fim da censura à correspondência não vai significar o fim daquele procedimento aos espectáculos em geral e às fitas em particular. Com efeito, a partir dos anos vinte, a vigilância sobre os espectáculos acentua-se, havendo uma provável relação directa com os efeitos decorrentes da crescente instabilidade política e da necessidade de o poder republicano se proteger da erosão 
a que estava sujeito. Podemos constatá-lo logo em 1923, com a promulgação do novo regulamento geral para o Teatro Nacional de Almeida Garrett, onde ficam excluídas do repertório "as obras atentatórias da moral social e da moral privada, as que desprestigiem as instituições do estado e ofendam os sentimentos patrióticos do povo português, e aquelas que pela incultura da sua forma literária não forem dignas da primeira cena do pais" (Decreto 9088, 1923: art.o 52).

A explicar este procedimento estará o facto de que o fim da guerra e do sidonismo não foi sinónimo de apaziguamento social e político. Pelo contrário, a sociedade portuguesa depois do conflito, e à semelhança de outras na Europa, confrontou-se com situações nada propiciatórias à sua estabilização. A inflação, que foi uma das maiores da Europa entre 1918 e 1924, conduzindo à implementação de uma impopular política fiscal, terá contribuído para a agitação operária, particularmente até 1920, materializada inúmeras vezes em greves, e a um progressivo desencanto das classes médias em relação ao republicanismo ante o seu receio da proletarização.

Por outro lado, entre 1919 e 1923, assistimos ao regresso de variadíssimos focos de agitação política. Em 1919 é instaurado durante um mês a Monarquia do Norte por Paiva Couceiro. De 19 para 20 de Outubro de 1921 deuse a Noite Sangrenta, revolução que forçou o governo conservador de António Granjo à demissão e na qual perderam a vida Machado Santos e o próprio António Granjo. Todas estas situações, no seu conjunto, contribuem para explicar a existência de 10 ministérios entre Março de 1919 e Maio de 1921 (Ramos, 1994c: 597-624), e terão obrigado o poder a reprimir alguma tendência crítica que emergisse através das peças de teatro levadas à cena no principal palco do pais.

Esta vigilância aplicar-se-á igualmente ao cinema. Entre Fevereiro de 1925 e Fevereiro de 1926 surgem três diplomas onde as fitas passam a ser objecto de restrições. Primeiramente, de forma genérica, passa a ser "proibida nos salões cinematográficos a exibição de fitas contrárias à moral e bons costumes" (Lei 1748, 1925: art.o 1º). Depois, em 1925, as empresas de espectáculos cinematográficos estavam "obrigadas a comunicar com a antecedência mínima de vinte e quatro horas, em Lisboa à Inspecção Geral dos Teatros, e nas demais terras do país às autoridades administrativas, como representantes daquela para este efeito, os títulos e assuntos das películas novas e o dia em que [fossem] apresentadas ao público".

Insistia-se também no formulário da lei anterior ao serem "rigorosamente interditas as exibições perniciosas para a educação do povo, incitamento ao crime e atentados à moral social". Os menores de 12 anos, estavam impedidos de entrar neste tipo de espectáculos, "quando desacompanhados dos pais, tutores, professores ou pessoa responsável pela sua guarda". Exceptuavam-se os casos em que as empresas fossem "autorizadas a organizar sessões diurnas exclusivamente dedicadas a crianças, nas quais se [exibissem] películas instrutivas, como representação de viagens, cenas históricas e outras de carácter educativo, moralizador ou patriótico" (Decreto 10573, 1925: art. $^{\circ}$ s $11^{\circ}-15^{\circ}$ ).

Finalmente, em Fevereiro de 1926, três meses antes do 28 de Maio, era de novo reiterada a proibição de exibir "fitas cujo assunto possa afectar a moral e os bons costumes". Os menores de 15 anos estavam agora proibidos de assistir à exibição de fitas que pudessem "sugestionar a prática de actos menos conformes com a moral social". Por último, a censura às fitas seria feita, "em regra, no primeiro dia da sua exibição, excepto nos casos em que os interessados requeiram a sua antecipação, para se evitarem às empresas cinematográficas transtornos de natureza técnica e financeira", ou, nos casos em que houvesse abusos e infracções, a Inspecção poderia exercer a "censura prévia das fitas" (Decreto 11459, 1926: art. ${ }^{\circ} 1^{\circ}-6^{\circ}$ ).

São conhecidas as dificuldades enfrentadas pelos governos republicanos a partir dos anos vinte, quer pelas razões socio-económicas anteriormente apontadas, quer pelo progressivo perfilamento no horizonte de alternativas políticas conservadoras oriundas dos sectores católicos ou integralistas, quer ainda pelo crescente protagonismo político de altas patentes do Exército, que, no seu conjunto, se traduziram num progressivo crescimento da instabilidade política e na criação de um clima conspirativo. As medidas aplicadas são em primeira instância um reflexo dessa instabilidade, surgindo-nos indistintas relativamente à cor política dos governantes. Quer o decreto de 1923, quer o de 1926, surgem de governos conservadores de António Maria da Silva, o primeiro diploma de 1925 emana do ministério de José Domingues dos Santos, que assumiu uma governação à esquerda, e o segundo do mesmo ano, é do tempo de Vitorino Guimarães, uma coligação entre democráticos, "alvaristas" e independentes (Ramos, 1994c: 621-628; Serra, 1990: 75-83). Ou seja, a motivação censória não radica em razões do foro partidário, mas na necessidade de auto-protecção do poder republicano ante as ameaças a que estava sujeito.

Analisando os critérios de censura no seu conjunto, podemos verificar que se cruzam diversas ordens de preocupações. As instituições do estado, a segurança, o cânone estético-literário, o patriotismo e a moral social e privada são as áreas que estavam sujeitas ao olhar vigilante do poder. No entanto, na aferição das peças ou das fitas não predomina a objectividade. Os decretos não definem alguns dos conceitos utilizados, nomeadamente o que se entende por "desprestígio das instituições, crime, incultura literária, sentimentos patrióticos ou moral social e privada". Consequentemente, impera a subjectividade interpretativa, que em última instância, é favorável aos intentos defensivos do poder. 
Apesar desse vazio conceptual parecem-nos ainda evidentes, tal como no início do regime, os intuitos republicanizadores. Efectivamente, quer aquilo que se considera "pernicioso para a educação do povo, ou que fosse ofensivo para os sentimentos patrióticos do povo português" teria subjacente a noção de patriotismo, o substrato ideológico mais profundo que o novo regime tentou inocular na população, no lugar da cultura clerical e monárquica do anterior. Para esse efeito, o republicanismo criou uma nova moral que, no lugar da anterior - revelada e transcendente, - apostasse em principios imanentistas, tendo por base a crença na progressiva perfectibilidade humana.

\begin{tabular}{llll}
\hline Critérios de censura & 1923 & 1925 & 1926 \\
\hline Obras atentatórias à moral social & $\times$ & $\times$ & $\times$ \\
\hline Obras atentatórias à moral privada & $\times$ & \\
\hline Desprestigio das instituições do estado & $\times$ & \\
\hline Ofensa aos sentimentos patrióticos do povo português & $\times$ & \\
\hline Incultura da forma literária & $\times$ & \\
\hline Atractivo principal constituído pela parte material e realização cénica & $\times$ & \\
\hline Perniciosas para a educação do povo & $\times$ & $\times$ \\
\hline Incitamento ao crime & \multicolumn{2}{|c}{$\times 1$} \\
\hline
\end{tabular}

(1923: Decreto 9088; 1925: Lei 1748; Decreto 10573; 1926: Decreto 11459)

É também essa ideia que está subjacente à inclusão da moral social enquanto critério avaliador da censura. Tratase de uma moral sem Deus, "assente na auto-suficiência autárquica do homem, entendido como ser naturalmente social e histórico". Ou seja, da inserção do homem no meio - social e geográfico - decorria um conjunto de regras elevadas a princípios de conduta, que seriam o desenvolvimento de "um amor consciente e raciocinado" pela "região onde nasceu, a pátria em que vive, a humanidade a que pertence". Esta moral social, que significava a expulsão de Deus de praticamente todas as esferas de influência - com excepção para o domínio privado - significava também a sua substituição pelo progressivo culto da pátria (Catroga 1991: 416-421).

Apesar do valor laicizante introduzido pelo republicanismo na vigilância aos espectáculos, parecenos notória a relação do discurso do poder com as diversas conjunturas que atravessou. Uma primeira, decorrente da agitação revolucionária e contra-revolucionária, outra, decorrente da conjuntura da guerra, e finalmente uma terceira, relacionável com a permanente instabilidade política que se instalou durante os anos vinte. Desse modo essa dependência terá obrigado o discurso do poder em matéria de espectáculos a tornar-se mais defensivo que afirmativo, não obstante o cariz laicizante introduzido na legislação.

\section{Referências bibliográficas e fontes}

CATROGA, Fernando (1991), O republicanismo em Portugal. Da formação ao 5 de Outubro, Coimbra, Faculdade de Letras.

Decreto (1911, 18 de Março), Colecção oficial da legislação portuguesa, $1^{1}$ série. Decreto (1912, 12 de Julho), COLP, 1 a série.

Decreto $\left(1913^{\mathrm{a}}{ }^{4} 4\right.$ de Janeiro), COLP, $1^{\text {a }}$ série. Decreto $\left(1913^{b}, 23\right.$ de Junho), COLP, $1^{\text {a }}$ série. Decreto 10443 (1925, 9 de Janeiro), Diário do Governo, $1^{\text {a }}$ série. Decreto 10573 (1925, 26 de Fevereiro), COLP, 1a série. Decreto 10798 (1925, 27 de Maio), COLP, 1ª série. Decreto 11459 (1926, 20 de Fevereiro), COLP, 1a série. Decreto 11459 (1926, 20 de Fevereiro), COLP, 1a série. Decreto 11462 (1926, 22 de Janeiro), COLP, 1a série. Decreto 13564 (1927, 6 de Maio), COLP, 1a série. Decreto 2270 (1916, 12 de Março), COLP, 1a série. Decreto 2308 (1916, 31 de Março), COLP, 1a série. Decreto 2352 (1916, 20 de Abril), COLP, 1 a série. Decreto 2538 (1916, 31 de Julho), COLP, 1a série. Decreto 3036 (1917, 16 de Março), COLP, 1ª série. Decreto 3098 (1917, 18 de Abril), COLP, 1 ${ }^{\text {a }}$ série. Decreto 3354 (1917, 10 de Setembro), COLP, 1a série. Decreto 4214 (1918, 13 de Abril), COLP, 1ª série. Decreto 4436 (1918, 17 de Junho), COLP, 1ª série. Decreto 4601 (1918, 12 de Julho), COLP, 1a série. Decreto 4927 (1918, 31 de Outubro), COLP, 1a série. Decreto 5455 (1919, 29 de Abril), COLP, 1ª série. Decreto 7772 (1921, 3 de Novembro), COLP, $1^{\text {a }}$ série. Decreto 8364 (1922, 25 de Agosto), COLP, 1 ${ }^{\text {a }}$ série. Decreto 9088 (1923, 6 de Setembro), COLP, 1a série. Decreto 9764 (1924, 4 de Junho), COLP, 1a série. Decreto 9764 (1924, 4 de Junho), COLP, 1 a série. Lei 495 (1916, 28 de Março), COLP, 1ª série. Lei 1368 (1922, 21 de Setembro), COLP, 1 a série. Lei 1633 (1924, 17 de Julho), COLP, 1ª série. Lei 1748 (1925, 14 de Fevereiro), COLP, 1a série. Lei 1748 (1925, 14 de Fevereiro), COLP, 1a série.

MARQUES, A. H. Oliveira (1980), A primeira república portuguesa, Lisboa, Livros Horizonte.

PAULO, Heloisa (1994), Estado Novo e propaganda em Portugal e no Brasil. O SPN/SNI e o DIP, Coimbra, Minerva.

RAMOS, Rui (1994a), "As guerras da República (1911-1917)", J. Mattoso, História de Portugal, 6, Lisboa, Círculo de Leitores, pp. 435-527.

--(1994c), "0 mito da política nacional", J. Mattoso, História de Portugal, 6, Lisboa, Circulo de Leitores, pp. 597-633.

SEABRA, Jorge (2007), África nossa. O império colonial na ficção cinematográfica portuguesa. 1945-1974, Coimbra, Faculdade de Letras.

SERRA, João B. (1990), "Do 5 de Outubro ao 28 de Maio: A instabilidade permanente", in António Reis, Portugal Contemporâneo, 3, Lisboa, Alfa, pp. 13-84.

TAYLOR, Philip M. (1982), British Official Attitudes Towards Propaganda Abroad, 1918-1939, London, The Macmillan Press. 